\title{
Reduction of waterborne microorganisms in treated domestic wastewater for reuse in agriculture: Comparison between floating media filter and sand filter
}

\author{
Chalanda Semsayun $^{1}$, Wilai Chiemchaisri ${ }^{{ }^{\dagger}}$, Chart Chiemchaisri $^{1}$, Nopparat Patchanee $^{2}$ \\ ${ }^{1}$ Department of Environmental Engineering, Faculty of Engineering, Kasetsart University, Bangkok 10900, Thailand \\ ${ }^{2}$ Fisheries Program, Faculty of Agriculture Technology, Sakon Nakhon Rajabhat University, Sakon Nakhon 47000, Thailand
}

\begin{abstract}
This study aims to investigate the use of a floating media filter (FMF) to eliminate waterborne microorganism in treated domestic wastewater for reuse in agriculture. A conventional sand filter (SF) was used concurrently to compare treated water quality. The total/fecal coliforms and somatic coliphage were employed as fecal indicators. The result showed that the FMF was fed with 3 times higher infiltration rate $\left(15 \mathrm{~m}^{3} / \mathrm{m}^{2} . \mathrm{h}\right)$ than that in the SF $\left(5 \mathrm{~m}^{3} / \mathrm{m}^{2} . h\right)$, in which both filters gave similar coliform removal at 6 hours operation. The somatic coliphage elimination tended to increase with operational time for the FMF while that of the SF showed decreasing trend. When a 24 hour continuous operation was applied for the FMF, it showed better removal of somatic coliphage (78\%), fecal coliforms (60\%) and total coliforms (56\%) than that of 6 hour operation. In conclusion, the FMF gave better performance than the SF did by producing a good quality of treated water for agriculture in terms of waterborne microorganisms including turbidity and suspended solids.
\end{abstract}

Keywords: Agriculture, Domestic wastewater, Floating media filter, Filtration, Microorganisms, Water reuse

\section{Introduction}

Domestic wastewater is normally treated by a complex process including a primary settling tank, aerobic biological degradation and secondary clarification in which the main objective is reduction of solids and biodegradable organic matter. By regulation of water quality standard of discharged wastewater in developed/developing countries, the treated domestic wastewater property resembles a surface water quality [1], thus a demand of the treated wastewater as recycled water becomes an alternative option in many countries in order to overcome water shortage especially for agriculture [2]. Nevertheless, waterborne microorganism remaining in a treated sewage is an important issue to endorse the safe use of municipal wastewater in agriculture. Risk to human health is caused by various kinds of infectious microorganisms such as viruses, bacteria and pathogenic protozoan/helminthes. Of these, bacteria are the most common of the microbial pathogens found in recycled water for agriculture [3]. The key fecal indicators recommended by WHO are total coliforms, fecal coliforms, and coliphage virus [3, 4]. Water quality standards for agriculture are usually set by interna- tional and local standards [5] in order to minimize health risks and environmental impacts.

In general, a treated effluent normally contains various waterborne microorganisms which need a process of disinfection [6]. However, this practice is rarely done especially in developing countries due to cost limitation [1]. Although disinfection has been performed in many developed countries in which chlorination is a popular method, fecal/total coliforms and E.coli have still been detected in ranges of 4.7-6.3 $\log \mathrm{CFU} / 100 \mathrm{~mL}$ and 4.7-5.4 $\log \mathrm{CFU} / 100 \mathrm{~mL}$ in reused treated sewage for agriculture purpose in Italy [3]. Besides, a drawback of this technique is a presence of the chlorine-derivative compounds such as Thihalomethane (THM), a carcinogenic compound, in the chlorinated effluent when high level of organic matter still remains in treated wastewater [7]. Another conventional process which is possibly applied to eliminate waterborne microorganisms in a wastewater is sand filtration $[3,8]$. For the best treatment system, the average log removals were 2.2-3.5 for pathogenic human, Novovirus and Adenovirus; and 4.3-5.2 and 4.6-5.4 for indicator viruses and bacteria, respectively [8]. However it is commonly limited by a clogged filter due to solid accumulation and biofilm development in a sand
This is an Open Access article distributed under the terms of the Creative Commons Attribution Non-Commercial License (http://creativecommons. org/ licenses/by-nc/3.0/) which permits unrestricted non-commercial use, distribution, and reproduction in any medium, provided the original work is properly cited.
Received August 3, 2015 Accepted November 12, 2015

${ }^{\dagger}$ Corresponding author

Email: fengwlc@ku.ac.th

Tel: +66-2-797-0999 Fax: +66-2-579-0730

Copyright (C) 2015 Korean Society of Environmental Engineers 
bed $[7,8,9]$. Recently, an alternative process, membrane filtration has been introduced due to a high water quality with low suspicious intermediate by-products including microorganisms $[7,10]$. The MBR provided the highest quality treated effluent and was the most robust treatment technology, remaining unaffected by an increase in influent grey water strength [10]. The ultra-membrane filtration is applied as a tertiary treatment process of domestic wastewater in Italy with higher water quality of 1.6-3.9 logCFU/100 $\mathrm{mL}$ of total coliforms [3]. Nevertheless, membrane filtration is costly for many developing countries including Thailand due to more energy consumption and chemicals for fouling control in operation [7]. An alternative option based on efficiency and simple operation is a floating media filter (FMF) which is successful in removing both colloids and waterborne microorganisms for surface water treatment [11]. The FMF functions as a flocculation tank/a sand filtration concurrently in a water-supply production process $[7,8,11]$. The FMF has a smaller footprint compared to conventional water treatment process. High removal rate of suspended solids and low head loss should be principal advantages of this process [12]. It was found to be effective for retaining particle and microorganisms in water containing high turbidity providing superior treated water quality [13]. From the point of view that agricultural activities require a water quality of low waterborne microorganisms including a need of large amount of treated water under low cost operation, the FMF is an interesting system for this situation. Thus, this study investigated efficacy of the FMF in removal of waterborne microorganisms in a treated sewage under 3 times higher hydraulic loading rate $\left(15 \mathrm{~m}^{3} / \mathrm{m}^{2} . \mathrm{h}\right)$ relative to that of a conventional sand filter. In addition, a sand filter was investigated in this study under its common operation $\left(5 \mathrm{~m}^{3} / \mathrm{m}^{2} . \mathrm{h}\right)$ [14] to compare water quality of treated wastewater. This study provides information for proposal of a floating media filter as a low cost system in water reuse of domestic wastewater for agriculture.

\section{Materials and Methods}

\subsection{Water Quality of Domestic Wastewater and Treated Wastewater}

The domestic wastewater from urban area in Bangkok has been treated by seven central wastewater treatment plants (CTPs). They have served a populated area of $192 \mathrm{~km}^{2}$ or $22 \%$ of total area of Bangkok [15]. The total treatment capacity of these CTPs is about $1,1016,800$ cum per day equivalent to $40 \%$ of the total wastewater volume [15]. Most of them are activated sludge process in which the design is focused on nutrients removal. All treated effluents are normally discharged into canals and delivered to Chao Phraya River. Because of the high volume of these discharged effluents daily in Bangkok, it is interesting in recycling as a raw water for water supply production and also other application such as agriculture, fisheries in near-by rural area etc. Hence, the water quality of the domestic wastewater (influent) and the treated wastewater (effluent) of seven CTPs was collected and analyzed for both chemical and biological characteristics. The water samples (influent and effluent) of each CTP were collected in 3 rounds (August 2012, October 2012 and January 2013). Then, the water quality of the treated wastewater was evaluated for recycling pur- pose based on available standard of reused water for agriculture in the world.

\subsection{Set up of Floating Media Filter and Sand Filter and Operational Condition}

The floating media filter (FMF) and the sand filter (SF) were installed at the same location at one of the CTPs in Bangkok during June 2012-Jan 2013. The selected CTP is the conventional activated sludge process with a treatment capacity of 40,000 cum per day. Its treated domestic wastewater was used as a feed into both system. The FMF unit was made of acrylic material, 0.1 m diameter, 1.6 $\mathrm{m}$ length (Fig. 1) containing $0.6 \mathrm{~m}$ depth of the floating plastic media ( $3.8 \mathrm{~mm}$ polypropylene bead). Because high removal of microorganisms was found when the infiltration rate of the floating media filter were $10-15 \mathrm{~m}^{3} / \mathrm{m}^{2} . h$ [13], therefore, in this experiment the infiltration rate of the FMF was selected at a constant rate of $15 \mathrm{~m}^{3} / \mathrm{m}^{2}$.h for all runs for a purpose of higher volume production of filtrate. Although it is reported that a FMF could be continuously operated for 8 hours before breakthrough of particles started taking place [7], in this study, a 6 hour operation was selected, which is a recommended optimum period for high elimination rate of coliform bacteria, while a longer period is better for coliphage removal [13].

Thus the FMF was carried out in 2 operational times: RUN1: 6 hours per day; and RUN2: 24 hours per day. For both RUNs, the operation was conducted for 4 rounds and one round per month during June 2012-Sep 2013 (RUN1) and during Oct 2012-Jan 2013 (RUN2). One round was five days operation continuously. This practice was performed because of seasonal variation of indigenous microorganisms in the treated domestic wastewater. In total, there were 20 days of FMF operational period per RUN. In addition, in order to reveal mechanisms of removal of waterborne microorganism indicators in both FMF and SF systems, the microorganisms were determined at every 2 hour intervals in the effluent of both filters for RUN1. In parallel to the FMF operation, the sand filter (SF), a conventional pretreatment process for microorganism removal, was set up in order to compare water quality

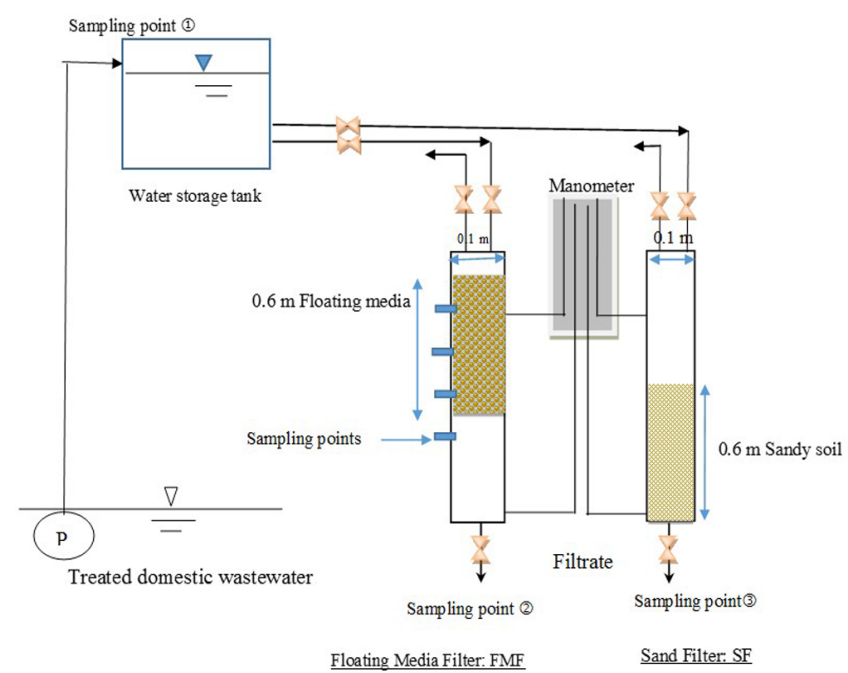

Fig. 1. Set-up of the floating media filter and sand filter. 
of the filtrate. The SF unit had a similar size and material made of as that of the FMF. It was filled with sandy soils $(1.1 \mathrm{~mm}$ size) with a depth of a $0.6 \mathrm{~m}$. Similarly to other previous studies, the infiltration rate of the sand filter in this experiment was limited to only $5 \mathrm{~m}^{3} / \mathrm{m}^{2} . \mathrm{h}$, which is a typical infiltration rate of a sand filter and running for 6 hours due to limitation of head loss from clogging in a sand bed [14]. For this reason, the infiltration rate of the sand filter was three times lower than that of FMF [14]. Therefore only the FMF system could be operated for 24 hours continuously. It was noted that periodical cleanings of the FMF and the SF were accomplished by using air scouring and water backflushing after finishing the filtration of 6 hours or 24 hours.

\subsection{Analysis of Water Samples}

The physical and chemical parameters were analyzed as according to APHA [16]. Total organic carbon was determined by TOC analyzer (Shimadzu). Total coliforms and fecal coliforms were enumerated by membrane filter technique [16]. Somatic coliphage was quantified by a plague forming assay using double agar overlay technique $[2,13]$. The somatic coliphage was harvested from a water sample by centrifugation of a sample at 9,000 rpm, $10 \mathrm{~min}$, $4^{\circ} \mathrm{C}$. Briefly, the precipitate was filtrated through a cellulose acetate membrane $(0.45 \mu \mathrm{m})$ for bacteria elimination. Then $1 \mathrm{~mL}$ filtrate was mixed with a $4 \mathrm{~mL}$ soft nutrient agar $\left(40^{\circ} \mathrm{C}\right), 0.5 \mathrm{~mL} \mathrm{CaCl}_{2}$ and the culture of young E.coli (TISTR780) host cells (4-6 h culture), then the mixture was poured onto Nutrient agar medium. The plate was incubated overnight at $37^{\circ} \mathrm{C}$. Then an appearance of clear circle zone indicated a lysis of E.coli host cells infected by one somatic coliphage called a plaque of somatic coliphage. The number of plaques per plate was counted and calculated as plaque forming unit, $\mathrm{PFU} / \mathrm{mL}[2,13]$.

\section{Results and Discussion}

\subsection{Characteristics of Domestic Wastewater and Treated Effluent in Relation to Agricultural Reuse}

Table 1 shows range and average characteristics of domestic wastewater and the treated wastewater of seven CTPs in Bangkok. Compared to common urban wastewaters worldwide, the domestic

Table 1. Water Properties of Influent and Effluent of Seven Central Wastewater Treatment Plants in Bangkok

\begin{tabular}{|c|c|c|c|c|c|c|c|c|c|}
\hline \multirow{2}{*}{ Parameters (mg/L) } & \multirow{2}{*}{ Influent } & \multirow{2}{*}{ Effluent } & \multirow{2}{*}{$\begin{array}{c}\% \text { Average } \\
\text { Removal }\end{array}$} & \multirow{2}{*}{$\begin{array}{c}\text { Thailand } \\
\text { WWTP Effluent } \\
\text { Standard }\end{array}$} & \multirow{2}{*}{$\begin{array}{c}\text { Thailand Surface } \\
\text { Water Quality for } \\
\text { Agriculture }\end{array}$} & \multicolumn{4}{|c|}{ Standard of Water Reuse } \\
\hline & & & & & & $\operatorname{Japan}^{\mathrm{b}}$ & USEPA $^{b}$ & Australia ${ }^{c}$ & Israel $^{\mathrm{C}}$ \\
\hline $\mathrm{pH}^{\mathrm{a}}$ & $\begin{array}{l}7.05 \pm 0.20 \\
(6.70-7.42)\end{array}$ & $\begin{array}{l}7.22 \pm 0.29 \\
(6.70-7.78)\end{array}$ & - & $5.5-9.0$ & $5-9$ & $5.8-8.6$ & $6-9$ & - & $6-9$ \\
\hline DO & ND & $\begin{array}{c}6.6 \pm 0.0 .9 \\
(5.1-9.0)\end{array}$ & - & - & $\geq 4$ & - & $0.03-0.05$ & - & 0.5 \\
\hline Turbidity & $\begin{array}{r}36.32 \pm 30.67 \\
(12.5-107.0)\end{array}$ & $\begin{array}{l}4.98 \pm 3.28 \\
(1.8-13.7)\end{array}$ & 86.5 & - & - & $\leq 10$ & $\leq 30$ & - & - \\
\hline Color $^{\mathrm{e}}$ & $\begin{array}{c}12.91 \pm 23.07 \\
(1.2-107)\end{array}$ & $\begin{array}{l}2.87 \pm 2.52 \\
(0.05-9.98)\end{array}$ & 77.7 & - & - & $\leq 40^{*}$ & - & - & - \\
\hline $\mathrm{BOD}_{5}$ & $\begin{array}{l}30.0 \pm 11.3 \\
(12.5-52.5)\end{array}$ & $\begin{array}{c}6.0 \pm 3.9 \\
(2.2-16.2)\end{array}$ & 80.0 & $\leq 20$ & $\leq 2$ & $\leq 10$ & $\leq 30$ & $<20$ & 25 \\
\hline COD & $\begin{array}{l}100.4 \pm 31.1 \\
(40.0-160.2)\end{array}$ & $\begin{array}{l}29.7 \pm 5.9 \\
(6.3-82.7)\end{array}$ & 70.0 & - & - & - & - & - & - \\
\hline TKN & $\begin{array}{l}10.04 \pm 3.90 \\
(5.04-19.60)\end{array}$ & $\begin{array}{l}3.2 \pm 1.87 \\
(1.12-8.4)\end{array}$ & 68.0 & $\leq 20$ & $\begin{aligned}\left(\mathrm{NH}_{3}\right. & \leq 0.5 \\
\mathrm{NO}_{3} & \leq 5)\end{aligned}$ & - & - & - & - \\
\hline Oil\&Grease & $\begin{array}{c}14.05 \pm 6.49 \\
(5.33-28.6)\end{array}$ & $\begin{array}{l}3.23 \pm 1.39 \\
(1.12-4.9)\end{array}$ & 77.0 & $<5$ & - & - & - & - & - \\
\hline TDS & $\begin{array}{c}256 \pm 85 \\
(124-430)\end{array}$ & $\begin{array}{c}292.00 \pm 73.98 \\
(128-388)\end{array}$ & - & - & - & - & - & - & - \\
\hline SS & $\begin{array}{c}58 \pm 61 \\
(15.0-243.3)\end{array}$ & $\begin{array}{c}7.52 \pm 5.73 \\
(2-23.3)\end{array}$ & 87.1 & $\leq 30$ & - & - & - & $<30$ & 20 \\
\hline Residual chorine & Not found & Not found & - & - & - & - & $<1$ & - & 0.5 \\
\hline E.coli $^{\mathrm{d}}$ & ND & ND & - & - & - & - & $<200$ & $<100$ & - \\
\hline Helminth egg $^{g}$ & Not found & Not found & - & - & - & - & - & - & - \\
\hline Total coliforms ${ }^{\mathrm{f}}$ & $\begin{array}{c}32.64 \times 10^{6} \pm 53.05 \times 10^{6} \\
\left(3.3 \times 10^{4}-2.1 \times 10^{8}\right)\end{array}$ & $\begin{array}{c}1.46 \times 10^{6} \pm 2.37 \times 10^{6} \\
\left(4.9 \times 10^{3}-1.0 \times 10^{7}\right)\end{array}$ & 95.5 & - & $\begin{array}{l}<5000^{\mathrm{k}} \text { and } \\
<20,000^{\mathrm{C}}\end{array}$ & $<1,000^{\mathrm{d}}$ & - & - & - \\
\hline Fecal coliforms ${ }^{\mathrm{f}}$ & $\begin{array}{c}14.6 \times 10^{6} \pm 16.25 \times 10^{6} \\
\left(3.3 \times 10^{5}-4.6 \times 10^{5}\right)\end{array}$ & $\begin{array}{c}0.91 \times 10^{6} \pm 1.33 \times 10^{6} \\
\left(9.3 \times 10^{3}-4.6 \times 10^{6}\right)\end{array}$ & 93.7 & - & $\begin{array}{c}<1000^{\mathrm{k}} \text { and } \\
<4,000^{\mathrm{C}}\end{array}$ & - & - & - & - \\
\hline Coliphage $^{\text {h }}$ & $\begin{array}{c}158.95 \pm 147.19 \\
(18-500)\end{array}$ & $\begin{array}{c}8.05 \pm 8.03 \\
(1-27)\end{array}$ & 94.9 & - & - & - & - & - & - \\
\hline
\end{tabular}

SD: standard deviation (min-max), ND: not determined, -: no recommended value, $\mathrm{n}=21$

${ }^{\mathrm{a}}$ unitless, ${ }^{\mathrm{b}}$ for non-contact purpose, ${ }^{\mathrm{c}}$ for agricultural Purpose, ${ }^{\mathrm{d}} \mathrm{CFU} / 100 \mathrm{~mL},{ }^{\mathrm{e}} \mathrm{Pt}$ Co unit, ${ }^{\mathrm{f}} \mathrm{MPN} / 100 \mathrm{~mL},{ }^{\mathrm{g}} \mathrm{No} . / \mathrm{L}$, ${ }^{\mathrm{h}} \mathrm{PFU} / \mathrm{mL}$, ${ }^{\mathrm{k}}$ for fisheries

*Pt Co unit 
wastewater of Bangkok has low organic matter because the sewer system is a combine type. This was due to over a half of water samples having been collected during rainy season (AugustSeptember). Besides, a very low concentration of biodegradable organic matter (BOD) with an average of $36.32 \pm 30.67 \mathrm{mg} / \mathrm{L}$ appeared relative to concentration of non-biodegradable organic matter (COD) of $100.4 \pm 31.1 \mathrm{mg} / \mathrm{L}$ resulting in a low BOD/COD ratio of 0.36. This is due to a common high degradation rate of organic matter while the wastewater was delivered in sewer under tropical climate [1]. In addition to the organic matter, other parameters such as nitrogen concentration (TKN), solids (SS) concentration, showed the same trend as of BOD with the concentrations of $10.04 \pm 3.90 \mathrm{mg} / \mathrm{L}$ and $58 \pm 61 \mathrm{mg} / \mathrm{L}$, respectively. Total coliforms and fecal coliforms were in ranges of $3.3 \times 10^{4}-2.1 \times 10^{8} \mathrm{MPN} / 100$ $\mathrm{mL}$ and $3.3 \times 10^{5}-4.6 \times 10^{5} \mathrm{MPN} / 100 \mathrm{~mL}$, respectively, which are common ranges of domestic wastewater. Less somatic coliphage appeared in range of $18-500 \mathrm{PFU} / \mathrm{mL}$ comparatively to that in the domestic wastewater in Beijing, China $\left(2.81 \pm 1.51 \times 10^{4} \mathrm{PFU} / \mathrm{mL}\right)$ [2]. None of helminth eggs per liter was found in Bangkok's domestic wastewater. After treatment process, the water quality of the treated wastewater of all CTPs passed Thailand's standard regulation of discharged wastewater, which are $\mathrm{pH}$ (5.5-9.0), BOD ( $\leq 20 \mathrm{mg} / \mathrm{L}$ ), total nitrogen ( $\leq 20 \mathrm{mg} / \mathrm{L}$ ) and oil\&grease ( $<5 \mathrm{mg} / \mathrm{L}$ ). In consideration for agricultural reuse, these treated wastewaters cannot be directly recycled for some agricultural activities especially for aquaculture due to remaining organic matter (BOD) and nitrogen compounds. Common toxic nitrogen compound on fish in treated wastewater is ammonia of which $\mathrm{LD}_{50}$ is about $0.1-1.0 \mathrm{mg} / \mathrm{L}$ depending on fish species and also presence of some inorganic compounds in treated wastewater such as chloride [17].

For microorganism removal, although 93-96\% removal of total coliforms, fecal coliforms and somatic coliphages could be achieved in all CTPs, the amount of these microbial indicators in the treated wastewater was still over the limit concentration according to the standard of recycled water for agriculture in some countries such as Japan, America and Australia. Besides, their concentrations are over the recommended coliform concentrations of standard surface water quality for fisheries/agriculture in Thailand (Table 1). The effects of reclaimed domestic wastewater for irrigation on hydrological soil behavior and vegetable quality resulted in increased microbial contamination (E. coli: 3000 most probable number (MPN)/100 mL; faecal Streptococcus spp.: 1200 MPN/100 $\mathrm{mL}$ ) on the soil surface [18]. The fruits harvested from those plants irrigated by preliminary treated wastewater showed high contamination by total coliforms, Streptococcus spp. and Salmonella spp. especially in the case for fruits, which were located close to the contaminated soil surface [19].

\subsection{RUN1: 6 hours Operation of Floating Media Filter and Sand Filter}

\subsubsection{Removal of waterborne microorganisms in floating media} filter and sand filter

According to determination of microorganisms in 2 hour intervals, it showed that elimination of total coliforms, fecal coliforms and somatic coliphage by the SF decreased with time (Table 2). This indicates that a 6 hour-running was moderate achievement in removal of waterborne microorganisms in the treated wastewater by the SF. The average removal efficiencies were $39.9 \%, 34.8 \%$ and $53.8 \%$ for total coliforms, fecal coliforms and somatic coliphage, respectively. Higher elimination of somatic coliphage was found although its normal size is less than that of bacteria, about $0.1 \times 0.4$ micron. This indicates other removal mechanism of this micro-particles beside common solid retention in the sand bed. It is reported that viruses show different behaviors in a soil filter according to differences in virus surface properties such as hydrophobicity and charge, which are affected by soil characteristics such as $\mathrm{pH}$, ionic strength and temperature [11]. For example, F-specific coliphages were removed more efficiently than somatic coliphages during their passage through the sand filters [11]. Hence, the SF required more frequent water flushing of cover layer of condensed solids and biomasses on sand filter bed surface to recover efficiency in the next run. For the FMF (Table 2), it is clearly seen that the floating media gradually dropped its efficacy in elimination of total coliforms and fecal coliforms at 6 hours of operational period with insignificant efficiency in relation to that of the SF. For somatic coliphage, although there was no difference in the average removal between the SF (53.8\%) and the FMF (52.4\%), nevertheless increasing trend of somatic coliphage removal with operational time in the FMF showed from $52.1 \%$ at 2 hours operational time to $64.1 \%$ at 6 hours operational time. For better understanding of the floating media filter working on microorganisms removal, water sampling along the depths of the filter was carried out. The changes of coliforms bacteria and somatic coliphage along the depths of the floating media are shown in Fig. 2. It indicates that total coliforms were continuously removed throughout the depth of the floating media bed $(0 \mathrm{~cm}-75 \mathrm{~cm}$ depths $)$ while fecal coliforms showed better removal at only the top of the floating
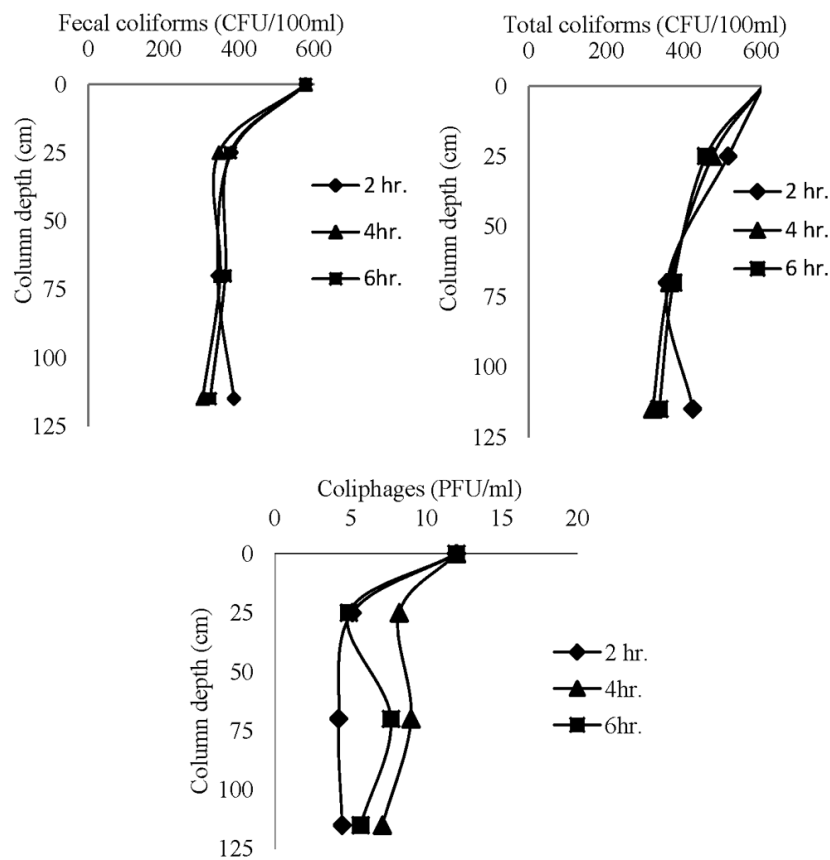

Fig. 2. Changes of total coliforms, fecal coliforms and somatic coliphage of the floating media filter (RUN1: a 6 hour operation). 
media bed (0-25 cm depth) and then the concentration of fecal coliforms kept consistency level between $25 \mathrm{~cm}$ and $75 \mathrm{~cm}$ depths. The difference in effective depths of total coliforms/fecal coliforms elimination is needed for future study in order to explain this. For the somatic coliphage, obvious changes of somatic coliphage concentration in the floating media depth was different from the coliforms removal. The increasing removal efficiency of somatic coliphage with time explained previously [11] that the retained solids in the upper zone of the floating bed enhanced the electrostatic forces at longer distances while the Van der Waals attraction at shorter distances, finally inducing viral particles attaching on the media surface [11]. Nevertheless, this phenomenon did not affect coliform bacteria due to their larger size relative to somatic coliphage size.

\subsubsection{Removal of chemical parameters}

The selected CTP produced effluent quality like the other plants did as shown in Table 2. General water quality of the treated wastewater appeared as of turbidity (10.82 \pm 6.8 NTU), color (1.71 \pm 0.4 S.U.), pH (7.65 \pm 0.6$)$, conductivity (391.62 \pm 127.6 $\mu \mathrm{s} / \mathrm{cm})$, DO $(7.35 \pm 0.21 \mathrm{mg} / \mathrm{L})$, SS $(17.41 \pm 8.51 \mathrm{mg} / \mathrm{L})$ and TOC $(7.82 \pm 2.86 \mathrm{mg} / \mathrm{L})$, nitrate $(2.3 \pm 0.32 \mathrm{mg} / \mathrm{L})$ and ammonia $(2.27 \pm 0.4$ $\mathrm{mg} / \mathrm{L}$ ). As discussed before, some parameters such as ammonia and BOD concentrations of this treated effluent did not pass the standard of surface water quality for agriculture/fisheries of Thailand. In experiment, the effluent from this CTP was employed as a feed for 2 types of filters with different infiltration rates according to its performance: FMF $\left(15 \mathrm{~m}^{3} / \mathrm{m}^{2} . \mathrm{h}\right)$ and $\mathrm{SF}\left(5 \mathrm{~m}^{3} / \mathrm{m}^{2} . \mathrm{h}\right)$. It is noted that the feed flow rate could not be conducted higher than $5 \mathrm{~m}^{3} / \mathrm{m}^{2}$.h for the SF due to increasing head-loss from clogging problem. Because a main mechanism of SF is particle retention in soil pores, larger particles are easily removed by this kind of filter. Thus, it showed that the SF produced a good quality of filtrate with turbidity of $1.27 \pm 0.28$ NTU and suspended solids of $2.34 \pm 0.84 \mathrm{mg} / \mathrm{L}$ (Table 3) giving an efficacy of $87 \%-89 \%$ of turbidity/suspended solids removals. Nevertheless, the sand filter

Table 2. Changes of Waterborne Microorganism Indicators in the Treated Wastewater of CAS, Filtrates of Sand Filter/Floating Media Filter in Case of an Operational Time of 6 Hours (June2012-Sep 2012)

\begin{tabular}{|c|c|c|c|c|c|c|c|c|c|}
\hline \multirow[t]{2}{*}{ Microorganism } & \multirow{2}{*}{$\begin{array}{c}\text { Influent } \\
\text { (Treated wastewater) }\end{array}$} & \multicolumn{4}{|c|}{$\begin{array}{l}\text { Filtrate of Sand Filter } \\
\qquad\left(5 \mathrm{~m}^{3} / \mathrm{m}^{2} . \mathrm{h}\right)\end{array}$} & \multicolumn{4}{|c|}{$\begin{array}{l}\text { Filtrate of Floating Media Filter } \\
\qquad\left(15 \mathrm{~m}^{3} / \mathrm{m}^{2} . \mathrm{h}\right)\end{array}$} \\
\hline & & $2 \mathrm{~h}$ & $4 \mathrm{~h}$ & $6 \mathrm{~h}$ & Avg & $2 \mathrm{~h}$ & $4 \mathrm{~h}$ & $6 \mathrm{~h}$ & Avg \\
\hline $\begin{array}{l}\text { Total coliforms } \\
\text { (CFU/100 mL), Average }\end{array}$ & 604 & 363 & 393 & 447 & 401 & 363 & 451 & 503 & 439 \\
\hline SD & 355 & 284 & 320 & 306 & 290 & 240 & 336 & 350 & 292 \\
\hline \%Removal & - & 34.9 & 25.9 & 33.6 & 39.9 & 39.9 & 25.3 & 16.7 & 27.3 \\
\hline $\begin{array}{c}\text { Fecal coliforms } \\
\text { (CFU/100 mL),Average }\end{array}$ & 577 & 333 & 406 & 390 & 376 & 283 & 400 & 455 & 379 \\
\hline SD & 278 & 270 & 275 & 310 & 277 & 168 & 252 & 317 & 230 \\
\hline \%Removal & - & 42.3 & 29.6 & 32.4 & 34.8 & 60.0 & 30.7 & 21.1 & 34.3 \\
\hline $\begin{array}{l}\text { Somatic coliphage } \\
\text { (PFU/100 mL), Average }\end{array}$ & 1170 & 510 & 510 & 600 & 540 & 560 & 690 & 420 & 556 \\
\hline $\mathrm{SD}$ & 208 & 179 & 152 & 149 & 63.4 & 242 & 167 & 81 & 143 \\
\hline \%Removal & - & 56.4 & 56.4 & 48.7 & 53.8 & 52.1 & 41.0 & 64.1 & 52.4 \\
\hline
\end{tabular}

SD: Standard Deviation, CFU: colony forming unit, PFU: Plaque forming unit

Table 3. Chemical Properties of Influent (Treated Effluent of the studied CAS) and Filtrates of the Sand Filter and the Floating Media Filter

Filtrate, average \pm SD (\% Removal)

\begin{tabular}{|c|c|c|c|c|c|}
\hline \multirow{2}{*}{ Parameters } & \multicolumn{3}{|c|}{6 h Operation } & \multicolumn{2}{|c|}{24 h Operation } \\
\hline & Influent & $\begin{array}{c}\mathrm{SF} \\
\left(5 \mathrm{~m}^{3} / \mathrm{m}^{2} \cdot h\right)\end{array}$ & $\begin{array}{c}\text { FMF } \\
\left(15 \mathrm{~m}^{3} / \mathrm{m}^{2} . h\right)\end{array}$ & Influent & $\begin{array}{c}\text { FMF } \\
\left(15 \mathrm{~m}^{3} / \mathrm{m}^{2} . h\right)\end{array}$ \\
\hline Turbidity (NTU) & $10.8 \pm 6.8$ & $1.27 \pm 0.28$ & $3.58 \pm 1.95(67)$ & $16.99 \pm 9.19$ & $3.07 \pm 1.10$ \\
\hline Color (S.U.) & $1.7 \pm 0.4$ & $1.06 \pm 0.11(41)$ & $1.34 \pm 0.28$ & $2.67 \pm 2.10$ & $1.33 \pm 0.48(50)$ \\
\hline $\mathrm{EC}(\mu \mathrm{s} / \mathrm{cm})$ & $391.6 \pm 127.6$ & $393.51 \pm 104.44$ & $396.28 \pm 104.22$ & $369.1 \pm 78.0$ & $335.7 \pm 30.0$ \\
\hline $\mathrm{pH}$ & $7.65 \pm 0.60$ & $7.59 \pm 0.43$ & $7.69 \pm 0.50$ & $7.06 \pm 0.23$ & $7.09 \pm 0.21$ \\
\hline SS (mg/L) & $17.41 \pm 8.51$ & $2.34 \pm 0.84(87)$ & $5.60 \pm 3.19(68)$ & $36.2 \pm 18.10$ & $5.95 \pm 4.02(84)$ \\
\hline DO (mg/L) & $7.35 \pm 0.31$ & $6.38 \pm 0.53$ & $6.86 \pm 0.45$ & $6.40 \pm 0.65$ & $4.80 \pm 0.46$ \\
\hline $\mathrm{NO}^{-}{ }_{3}-\mathrm{N}(\mathrm{mg} / \mathrm{L})$ & $2.30 \pm 0.18$ & $2.04 \pm 0.32$ & $2.08 \pm 0.19(10)$ & $2.96 \pm 1.29$ & $2.85 \pm 1.04$ \\
\hline $\mathrm{NH}^{+}{ }_{4-} \mathrm{N}(\mathrm{mg} / \mathrm{L})$ & $2.27 \pm 0.40$ & $1.79 \pm 0.10$ & $1.82 \pm 0.58(20)$ & $2.64 \pm 0.16$ & $2.07 \pm 0.57$ \\
\hline $\mathrm{TN}$ (mg/L) & $5.62 \pm 1.37$ & $5.67 \pm 2.22(-)$ & $5.79 \pm 1.87(-)$ & $7.69 \pm 0.44$ & $7.57 \pm 0.58$ \\
\hline TOC (mg/L) & $7.82 \pm 2.86$ & $6.33 \pm 2.75(19)$ & $6.30 \pm 2.17(19)$ & $5.63 \pm 3.29$ & $4.46 \pm 2.27(21)$ \\
\hline
\end{tabular}

Influent: the treated domestic wastewater, SF: Sand Filter, FMF: Floating Media Filter, SD: standard deviation 
showed low efficacy (19\%-41\%) in removal of nitrogenous compounds, inorganic ions including organic matter. The remaining ammonium, nitrate, and TOC in the effluent were $1.79 \pm 0.10 \mathrm{mg} / \mathrm{L}$, $2.04 \pm 0.32 \mathrm{mg} / \mathrm{L}$ and $6.33 \pm 2.75 \mathrm{mg} / \mathrm{L}$, respectively. It indicates low adsorption and biodegradation of these compounds inside the sand bed.

In consideration of the FMF, because high removal rate of suspended solids and low head loss should be principal advantages of this process, it was fed with 3 times higher flow rate $\left(15 \mathrm{~m}^{3} / \mathrm{m}^{2} . \mathrm{h}\right)$ as of the sand filter. Nevertheless, slightly higher concentrations of turbidity (3.58 \pm 1.95 NTU) and suspended solids (5.60 \pm 3.19 $\mathrm{mgSS} / \mathrm{L}$ ) in the FMF filtrate appeared relative to that of the SF. This resulted from a higher infiltration rate of the FMF. It gave more particle/colloidal passing through the voids in the floating bed [20]. In conclusion, the filtrates from both SF and FMF had a very good water quality as a recycled water in term of turbidity which is suggested by many international guidelines (Table 1). Nevertheless they were still limited in aquaculture application especially in Thailand due to higher levels of some nitrogenous compounds. Compared to the $\mathrm{SF}$, there was insignificance for concentrations of ammonium, nitrate, TOC, color in the FMF infiltrate $(\mathrm{P}>0.05)$.

\subsection{RUN2: 24 Hours Operation of Floating Media Filter}

The result of a 6 hours operation suggests that the floating media filter showed better removal on somatic coliphage when operation time was increased. Thus, a 24 hours operation of the FMF was carried out in order to reveal maximum capability of the FMF in removal of microorganisms in extended time. In case of waterborne microorganisms, the fed water qualities of the FMF in RUN2 contained microorganism ten times higher than that of RUN1. This was due to a different time frame of experiment of RUN2 which was carried out during Oct 2012-Jan 2013 (RUN2). During this time, Bangkok had a problem of major flooding which effected normal situation of CTPs operation. Although there was higher amount of microorganisms in the fed, the 24 hours operation of the $\mathrm{FMF}$ gave better removal efficiencies of $78 \%$ somatic coliphage, $60 \%$ fecal coliforms and $56 \%$ total coliforms removals (Fig. 3). This is because 24 hours is enough time for microorganisms growing on the plastic media as shown by slime on the plastic media surfaces, therefore, it is possible that more microorganisms adhered to these microbial biofilms. In addition to that, the microorganisms could be adsorbed on suspended solids which were trapped inside the floating media bed. It is reported that the entrapment of microorganisms in larger flocculated particles played a minor role in removing microorganism in the floating media filter especially for smaller size microorganism like somatic coliphage. Virus removal was predominately due to adsorption of the negatively charged virus onto the positively charged flocs and subsequently removal of the flocs by filter [21].

In addition to microorganism removal, the chemical properties of the treated effluent were: turbidity (3.07 $\pm 1.1 \mathrm{NTU})$, color (1.33 \pm 0.04 S.U), $\mathrm{pH}$ (7.03 \pm 0.21$)$, conductivity $(335 \pm 30.0 \mu \mathrm{s} / \mathrm{cm})$, DO $(4.8 \pm 0.46 \mathrm{mg} / \mathrm{L}), S S(5.95 \pm 4.02 \mathrm{mg} / \mathrm{L})$ and TOC $(4.46 \pm 0.58$ $\mathrm{mg} / \mathrm{L})$, TN $(7.57 \pm 0.58 \mathrm{mg} / \mathrm{L})$, nitrate $(2.85 \pm 1.04 \mathrm{mg} / \mathrm{L})$ and ammonia $(2.07 \pm 0.57 \mathrm{mg} / \mathrm{L})$. It showed better efficiency due to a longer operation of the FMF which found for SS (from 68\% to 84\%), turbidity (from $67 \%$ to $82 \%$ ), and color (from $21 \%$ to $50 \%$ ). This is because the retained suspended solids inside the FMF bed functioned as

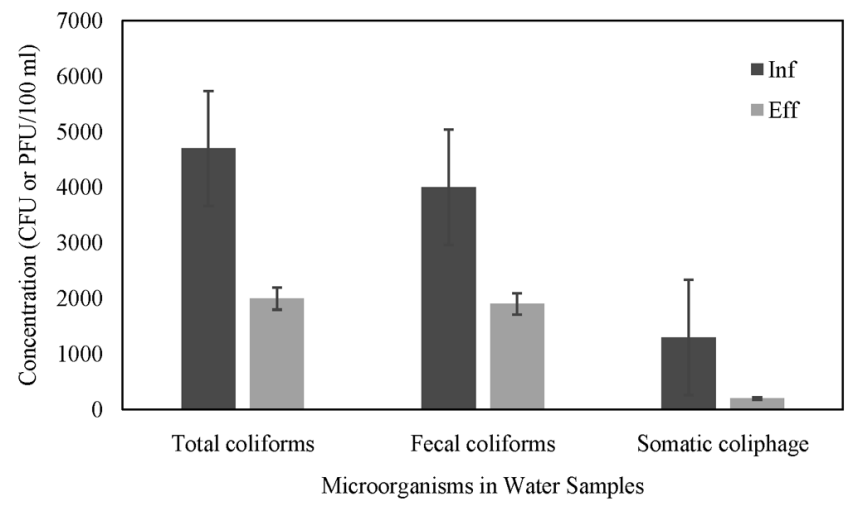

Fig. 3. Average concentration of total coliforms, fecal coliforms and somatic coliphage in the influent and filtrate of the FMF at RUN2 (a 24 hour operation) under infiltration rate of $15 \mathrm{~m}^{3} / \mathrm{m}^{2} . \mathrm{h}$

a micro-particle filter subsequently in reducing void ratio of the floating media bed. This is an increasing particle size effect similarly found in treatment of surface water with high turbidity by the floating media filter with coagulant addition. This condition gave better removal of turbidity and suspended solids by flocs formation in the floating media bed [20]. Overall results suggest that a 24 hour operation of the floating media filter produced better water quality in terms of suspended solids and turbidity removal than that of a 6 hour operation.

In consideration of the application of water recycled for agriculture purpose, the FMF produced better quality of discharged effluent in which the property is close to surface water quality. From the recommended parameters in many guidelines of water reuse for agriculture in Australia, USEPA and Israel (Table 1), the effluent from the FMF could be applied as recycled water. In conclusion, the floating media filter not only gave higher efficient in volume of treated water, but also achieved better water quality in terms of waterborne microorganisms, turbidity and suspended solids.

\section{Conclusions}

Both floating media filter and sand filter were close in performance for removal of waterborne microorganisms in treated domestic wastewater under operation of 6 hours. However, the floating media filter could increase the operational time to 24 hours with an infiltration rate of $15 \mathrm{~m}^{3} / \mathrm{m}^{2}$, which showed better removal of somatic coliphage (78\%), fecal coliform (60\%) and total coliforms (56\%). In conclusion, the floating media filter not only gave higher efficacy in voluminous treated water, but also produced better water quality in term of waterborne microorganisms as compared to the conventional sand filter.

\section{Acknowledgements}

This study was investigated under the project: Feasibility Study of Wastewater Reuse for Bangkok Metropolitan Authority (2012) in collaboration with the AUN/SEED-Net under cooperative research with industry program. 


\section{References}

1. Kumjaroen T, Chiemchaisri W, Chiemchaisri C. Colonization of microbial biofilms in pipeline of water reuse. Environ. Eng. Res. 2014;19:275-281.

2. Wu J, Li H, Huang X. Indigenous somatic coliphage removal from a real municipal wastewater by a submerged membrane bioreactor. Water Res. 2010;44:1853-1862

3. Vivaldi GA, Camposeo S, Rubino P, Lonigro A. Microbial impact of different types of municipal wastewaters used to irrigate nectarines in Southern Italy. Agri. Ecosys. Environ. 2013;181: 50-57.

4. WHO. Wastewater Use in Agriculture. vol. 2. Guidelines for the safe use of wastewater, excreta and greywater. Geneva: World Health Organization; 2006.

5. WHO. Guidelines for the safe use of wastewater, excreta and greywater. vol. 3. Wastewater and Excreta Use in Aquaculture. Geneva: World Health Organization; 2006.

6. Junli H, Li W, Nanqi R, Frang M. Disinfection effect on chlorine dioxide on bacteria in water. Water Res. 1997;31:607-613.

7. Chiemchaisri C, Passananon S, Ngo HH, Vigneswaran S. Enhanced natural organic matter removal in floating media filter coupled with microfiltration membrane for river water treatment. Desalination 2008;234:335-43.

8. Ari Kauppinen, Martikainen K, Matikka V, et al. Sand filters for removal of microbes and nutrients from wastewater during a one-year pilot study in a cold temperate climate. J. Environ. Manag. 2014;133:206-213.

9. Leverenz HL, Tchobanoglous G, Darby JL. Clogging in intermittently dosed sand filters used for wastewater treatment. Water Res. 2009;43:695-705.

10. Winward GP, Avery LM, Frazer-Williams R, et al. A study of the microbial quality of grey water and an evaluation of treatment technologies for reuse. Ecolo. Eng. 2008;32:187-197.

11. Chiemchaisri W, Chiemchaisri C, Dumrongsukit C, Threedeach, S, Ngo HH, Vigneswaran S. Removal of water-born microorganisms in floating media filter-microfiltration system for water treatment. Biores. Technol. 2011;102:5438-5443.

12. Tanaka Y, Miyajima K, Funakosi T, Chida S. Filtration of municipal municipal sewage by ring shaped floating plastic net media. Warter Res. 1995;29:1387-1392.

13. Chiemchaisri C, Chiemchaisri W, Kornboonraksa T, Dumrongsukit C, Threedeach S, Ngo HH, Vigneswaran S. Particle and microorganism removal in floating plastic media coupled with microfiltration membrane for surface water treatment. Water Sci. Tech. 2005;51:93-100.

14. Bangkok Metropolitan Authority. Feasibility study of wastewater reuse for Bangkok metropolitan authority. Bangkok, Thailand: 2013.

15. American Public Health Association (APHA). Standard methods for the examination of water and wastewater. 20th ed. Washington, DC: American Public Health Association; 1998.

16. Polngam, P, Chiemchaisri W, Kaewmanee A, Chiemchaisri C, Yamamoto K. Chemical characterization in correlation to toxicity evaluation for water reuse of solid waste leachates in the itMBR-RO system. J. Mater. Cycles Waste Manag. 2015;17:2:237-248.

17. Aiello R, Cirelli GL, Consoli S. Effects of reclaimed wastewater irrigation on soil and tomato fruits: a case study in Sicily (Italy). Agric. Water Manage. 2007;93:65-72.

18. Almuktar S.A.A.A.N, M Scholz M. Microbial contamination of Capsicum annuum irrigated with recycled domestic wastewater treated by vertical-flow wetlands. Ecolo. Eng. 2015;82: 404-414.

19. Chiemchaisri C, Panchawaranon C, Rutchatanunti S, Kludpiban A, Ngo HH, Vigneswaran S. Development of floating plastic media filtration system for water treatment and wastewater reuse. J. Environ. Sci. Health Part A. 2003;38:2359-2368.

20. Zhu B, Clifford DA. Chellam S. Comparison of electrocoagulation and chemical coagulation pretreatment for enhanced virus removal using microfiltration membranes. Water Res. 2005;39: 3098-3108. 